\title{
A Vinculação Afetiva para Crianças Institucionalizadas à Espera de Adoção
}

Affective Relations Among Institutionalized
Children Who Wait for Adoption

La Vinculación Afectiva para Niños Institucionalizados a la Espera de Adopción

Shimênia Vieira de Oliveira \&

Caio César Souza Camargo Próchno

Universidade Federal de Uberlândia

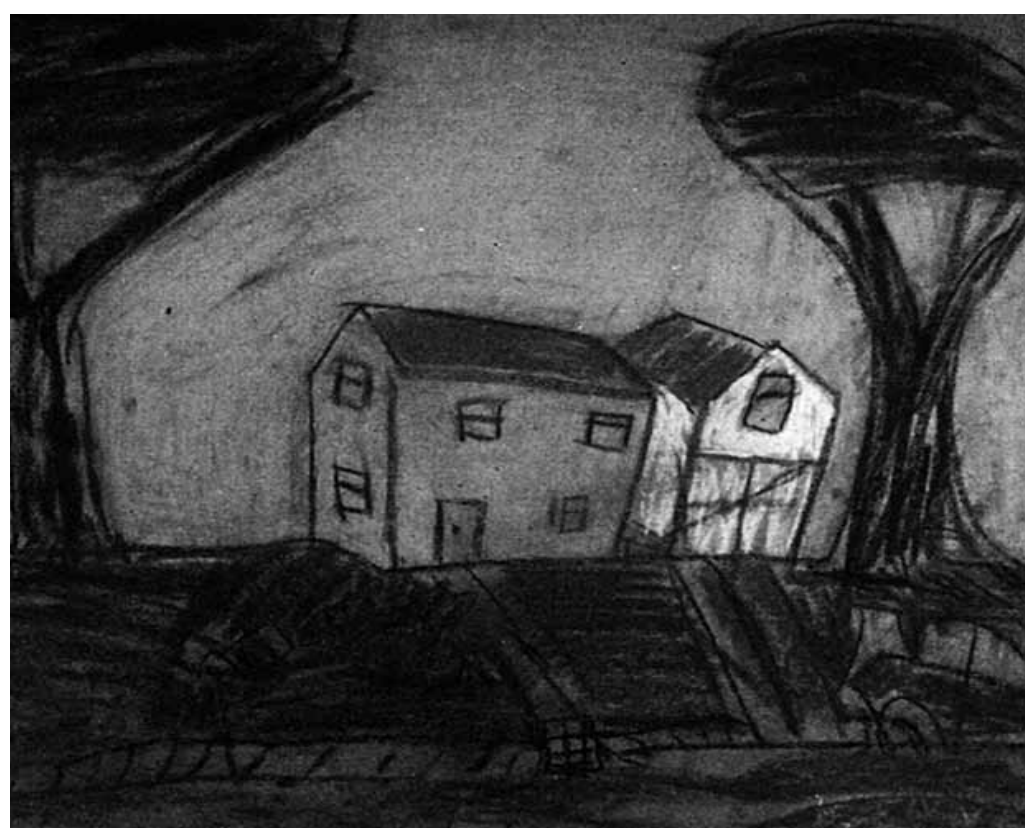


Resumo: Este trabalho aborda a compreensão de vivências afetivas de crianças institucionalizadas à espera de adoção. Os sujeitos da pesquisa foram quatro crianças (duas meninas e dois meninos), com idade entre seis e nove anos. Buscaram-se informações sobre a sua história de vida nos prontuários da instituição, e as crianças foram entrevistadas individualmente. Observando-as em brincadeiras, em atividades na instituição e por meio do desenho livre, puderam ser percebidos modos e sentidos de alguns laços afetivos significativos para elas. Neles constatou-se que as percepções daquelas crianças no que se refere à instituição não eram tão problemáticas como se poderia supor à primeira vista. Entre elas e as cuidadoras, verificaram-se igualmente relações com certo nível de afetividade. Após análise qualitativa de dados, pôde-se perceber que as crianças se vinculam positivamente à instituição, entretanto, manifestam o desejo de ter um lar. Outras categorias emergentes acerca do vínculo afetivo, além da proximidade com as atendentes, foram o brincar, as amizades e a distinção entre o bem e o mal. Pode-se dizer que tais crianças, embora tenham estabelecido vínculos de afetividade com a instituição, ainda são agenciadas por um imaginário em que o desejo de ter uma família se revela muito intenso e com possibilidades de realização. Conclui-se, com isso, que tais temáticas estão atreladas à possibilidade de a criança se relacionar com as demais pessoas de forma mais lúdica e simbólica.

Palavras-chave: Crianças institucionalizadas. Afetividade. Vínculo afetivo. Institucionalização.

Abstract: The present research sought to understand the affective relations among institutionalized children who wait for adoption. Four children (two girls and two boys) aged from six to nine years old participated in the study. Their life histories were examined in the documents of the institution and the children were interviewed individually. They were observed at play, in routine activities and in drawing sessions which revealed their feelings and behavioral orientations in terms of their affective attitudes and the significance of these attitudes. It was found that their perceptions with reference to the institution were not as problematic as might be supposed at first. Between the children and their caretakers a certain level of affectivity was observed. Following a qualitative analysis of the data it could be perceived that the children were positively linked to the institution. They did, however, manifest the desire for a home. Other categories of behavior used to identify feelings of affection included their play activities, friendships and the distinctions they made between good and evil. It can be said that the children observed, in spite of having established affective relations within the institution, still remained captivated by their own imaginations, longed for families and hoped for their inclusion in family situations. It was concluded that the themes of the study are related to the possibility of the child to establish relations with others in informal and symbolic manners.

Keywords: Institutionalized children. Affectivity. Affective relations. Institutionalization.

Resumen: Este trabajo aborda la comprensión de vivencias afectivas de niños institucionalizados a la espera de adopción. Los sujetos de la pesquisa fueron cuatro niños (dos niñas y dos niños), con edad entre seis nueve años. Se buscaron informaciones sobre su historia de vida en los prontuarios de la institución, y los niños fueron entrevistados individualmente. Observándolos en juegos, en actividades en la institución y por medio del dibujo libre, pudieron ser percibidos modos y sentidos de algunos lazos afectivos significativos para ellos. En ellos se constató que las percepciones de aquellos niños en lo que se refiere a la institución no eran tan problemáticas como se podría suponer a la primera vista. Entre ellos y las cuidadoras, se verificaron igualmente relaciones con cierto nivel de afectividad. Después del análisis cualitativo de datos, se pudo percibir que los niños se vinculan positivamente a la institución, mientras, manifiestan el deseo de tener un hogar. Otras categorías emergentes acerca del vínculo afectivo, además de la proximidad con las auxiliares, fueron el jugar, las amistades y la distinción entre el bien y el mal. Se puede decir que tales niños, aunque hayan establecido vínculos de afectividad con la institución, aún son agenciados por un imaginario en que el deseo de tener una familia se revela muy intenso y con posibilidades de realización. Se concluye, con eso, que tales temáticas están relacionadas a la posibilidad de que el niño se relacione con las demás personas de forma más lúdica y simbólica.

Palabras clave: Niños institucionalizados. Afectividad. Vínculo afectivo. Institucionalización.

Os processos de adoção, no atual contexto brasileiro, caracterizam-se por sérias dificuldades de ordem principalmente sociocultural e jurídica, tais como: extrema morosidade da Justiça no sentido de agilizar os diferentes casos de adoção e fatores de ordem mais eminentemente cultural, tais como o preconceito racial que impede as pessoas de adotarem crianças negras, por exemplo. Mesmo assim, tal panorama tem se modificado ao longo dos últimos anos, com novas pesquisas e reflexões que têm 
Conforme Peres (2006) assinala, a adoção se destacou no Direito romano, no qual obteve maior notoriedade; contudo, as primeiras referências legitimadas em normas para a prática da adoção constam nos Códigos de Manu e de Hamurabi, e desempenharam relevante função social e política na Grécia antiga. indicado um modo diferente de se lidar com esse tema, tornando cognoscíveis à população os aspectos inerentes a ele e à sua prática legal. Uma pesquisa realizada por Mariano e Rossetti-Ferreira (2008) fornece alguns subsídios que corroboram essa afirmativa. Elas traçaram em seu estudo um perfil das famílias biológicas, das adotantes e da criança adotada em 110 processos judiciais da comarca de Ribeirão Preto (São Paulo) entre 1991 e 2000. Nos processos de adoção analisados, foi constatada a prevalência de adoções prontas, ou seja, os adotantes já conheciam a criança, por intermédio de instituições ou de outros mediadores, e requeriam na Justiça a sua adoção. Além disso, os adotantes pertenciam às camadas médias e populares e manifestaram diversas motivações para a adoção, como a infertilidade e o vínculo com a criança. Outro dado que emergiu na pesquisa é de que são escassos os registros da etnia das crianças à espera de adoção, apesar de essa informação ser considerada uma característica relevante nos processos de adoção. No referido estudo, apurou-se que $70 \%$ das crianças tinham até um ano de idade, tendo sido registradas $60 \%$ de adoções de meninos e $40 \%$ de meninas.

Outros autores, como Weber (2003), ressaltam a prevalência de características bastante específicas que os pretensos adotantes buscam nas crianças para adotá-las. Geralmente, essas pessoas requerem bebês saudáveis, brancos e recém-nascidos, ou seja, com características físicas elaboradas a partir de um desejo ideal dos pretensos adotantes e que têm sido privilegiadas em detrimento das necessidades das crianças. Desse modo, segundo reafirmado por Mariano e Rossetti (2008), crianças mais velhas permanecem nas instituições de abrigo à espera de serem adotadas, ou de retornarem às suas famílias de origem, devido ao fato de apresentarem características menos desejadas, tais como: serem portadoras de algum tipo de deficiência física ou mental, serem maiores de dois anos, serem negras ou formarem grupos de um ou mais irmãos. Atualmente, campanhas de divulgação e a instituição de novas leis, como a criação do Cadastro Nacional de Adoção, têm tentado proporcionar maior visualização da adoção na sociedade, tanto na possibilidade de despertar o interesse das pessoas em adotar uma criança quanto na relevância do tema como objeto de estudo para pesquisas.

Nesse intuito, o objetivo deste trabalho foi compreender o modo de vivenciar a afetividade para crianças institucionalizadas à espera de adoção, buscando entender o modo de vinculação afetiva entre a criança e seus cuidadores, colegas e demais pessoas no abrigo e tentar identificar formas de vínculos saudáveis bem como possíveis vivências patológicas oriundas de uma ruptura de vínculos.

\section{Adoção}

A adoção é uma prática efetuada desde os tempos mais antigos. Conforme Peres (2006) assinala, a adoção se destacou no Direito romano, no qual obteve maior notoriedade; contudo, as primeiras referências legitimadas em normas para a prática da adoção constam nos Códigos de Manu e de Hamurabi, e desempenharam relevante função social e política na Grécia antiga. A adoção auxiliava na perpetuação dos conhecimentos, especialmente políticos, religiosos e sociais, dada a preocupação com os filhos do gênero masculino, que detinham a função de perpetuarem os rituais da família. Nesse sentido, Albuquerque (1983) ressalta que, inicialmente, a adoção possuía finalidades religiosas, políticas e econômicas. Contudo, atualmente, ela se caracteriza como uma prática eminentemente social e humanitária, constituindo a forma mais adequada para oferecer às crianças que necessitam de amparo e proteção um lugar para que possam se desenvolver e ter seus direitos garantidos. 
Por sua vez, como ponto de apoio, a instituição se transformou na alternativa mais apropriada para acolher crianças que, em conflito com a família de origem (conflito aqui entendido por situações de maus tratos, abusos, abandono, dentre outras), não se encontram em condições de permanecer em casa, ou no convívio da mesma, em situações com caráter de violação dos direitos da criança. De acordo com a Constituição Federal, no art. 227, do Capítulo VII,

caso impossível, absolutamente inviável
ou não recomendável a permanência
da criança e do adolescente em
companhia de seus pais, após esgotadas
as tentativas que nesse sentido deverão
ser obrigatórias e ex vi legis realizadas,
a colocação do jovem em família
substituta surge como a melhor forma
de superar a falta, o abuso ou a reiterada
e injustificável omissão de sua família
natural, garantindo aquele seu direito
fundamental de ser criado e educado no
seio de uma família, ainda que não seja a
de origem (inteligência da terceira parte
do citado art. 19 da Lei no $8.069 / 90$ ).
(p. 158)

O vínculo construído pela adoção tem como objetivo imitar a filiação natural, ou seja, aquela originada do sangue, geneticamente comprovada, que também é conhecida como a filiação civil. Valiko (2003) conceitua que a adoção é uma modalidade artificial de filiação pela qual se aceita como filho, de maneira voluntária e legal, um desconhecido na vida familiar. A adoção é definida como um ato de inclusão da criança ou do adolescente em uma nova família, de forma definitiva e com vínculo jurídico com caráter de filiação. Para tanto, é necessária que seja decretada a perda do poder familiar, cuja referência é explicitada no Estatuto da Criança e do Adolescente (ECA, 1990), segundo o art. 24 (p. 15): “a perda e a suspensão do pátrio poder serão decretadas judicialmente, em procedimento contraditório, nos casos previstos na legislação civil, bem como na hipótese de descumprimento injustificado dos deveres e obrigações a que alude o art. 22 ". As causas podem ser remetidas à morte dos pais ou do filho, à emancipação do filho, à maioridade do filho, à adoção do filho por terceiros ou à perda do pátrio poder em virtude de decisão judicial, segundo Lôbo (2006). Já o art. 22 do ECA (p. 14) prevê que "aos pais incumbe o dever de sustento, guarda e educação dos filhos menores, cabendo-lhes ainda, no interesse destes, a obrigação de cumprir e fazer cumprir as determinações judiciais". Portanto, após a destituição do poder familiar, fica a criança ou o adolescente à disposição para a adoção, e em consequência, à espera de sua inserção em uma família substituta.

Segundo Weber (2002), o objetivo principal da adoção precisa ser o de proteger a criança e não o que tem sido: a criança admitida como solução para a necessidade dos pais de formarem uma família. Há que se priorizar, de maneira contundente, a preparação das pessoas que desejam adotar uma criança, ou, como coloca Weber, estar atento para os mitos, como o fato de os pretensos adotantes optarem por crianças mais novas, bebês, praticamente, e com características físicas semelhantes às suas. Tal fato indica a procura por um ideal de filho para atender o desejo dos pais. Fatores como esse, sejam eles culturais, sociais, etc, influenciam a experiência de adoção no sentido de beneficiar os pais em detrimento da necessidade da criança. No Brasil, a história da adoção está vinculada ao abandono de crianças e é extremamente marcada por essa condição. Sartorelli e Claro (2003) destacam que tal situação não é recente, e que há a necessidade de avaliá-la de maneira total, complexa. Dessa forma, os autores apresentam uma crítica à escassez de estudos acerca desse assunto. Para Tabajaski e Chaves (1997), a adoção constitui uma das possíveis alternativas que se oferece às crianças em situação de abandono para que possam resgatar sua história e construir uma nova. Algumas vezes, ela se apresenta depois 
de um longo percurso marcado por privações e violência.

Dessa forma, torna-se difícil e doloroso o resgate de uma história de vida da própria criança para a construção de novas formas de relação, de vínculos com outra família ou com outras pessoas. Diante disso, propõe-se também que haja uma preparação dessas crianças para o ingresso em uma nova família. As crianças adotadas tardiamente, ou seja, com mais de dois anos de idade, muitas vezes refletem claramente essa preocupação dos profissionais que trabalham com adoção. No caso de uma adoção tardia, por exemplo, esse fato é protagonizado por crianças que possuem...

...histórias graves de negligência, abandono, violência e ainda com privações que se estendem ao sistema institucional no qual são inseridas. Muitas vivem longos períodos de abrigamento, vítimas da burocracia judiciária ou mesmo do caos familiar que impedem o desfecho final da perda de pátrio poder. (Tabajaski \& Chaves,1997, p. 1)

Adotar é ato de inclusão de um ser, seja criança, seja adolescente, em uma nova família, que também tem suas regras, seus costumes, sua dinâmica, assim como o sujeito que nela adentra o tem, e, na maioria das vezes, acrescido de dor e sofrimento em sua vivência com o outro (Cartilha da Adoção: $2^{a} \underline{a}$ Vara da Infância e da Juventude do Recife, 2004).

Para que ocorra essa inclusão, considerase fundamental a instauração do vínculo afetivo. O desenvolvimento humano na fase da infância, especificamente, implica um fator necessariamente preponderante na construção da identidade da criança e de sua relação com o outro. Esse fator é aqui denominado vínculo afetivo, e refere-se à capacidade do indivíduo de se vincular a outrem por meio de uma necessidade que vem acompanhada de um sentimento de estar junto com o outro, realizando movimentos de troca entre as partes. Como coloca Bussab (2003),

Um exame das principais características do desenvolvimento humano revela uma inseparabilidade entre as ligações afetivas e as demais trocas significativas através das quais apreendemos o mundo que nos cerca, conferimos significados e desenvolvemos habilidades. O processo de desenvolvimento humano pode ser concebido como sendo de co-educação. Desde muito cedo no desenvolvimento, apresentamos tendências para a regulação social recíproca, para compartilhamentos de atenção e de emoções, para o reconhecimento individual, para a formação de vinculações afetivas e para uma busca de referenciamento na figuras de apego para o entendimento de todas as situações cotidianas. (p. 7)

Há uma necessidade intrínseca no ser humano de se apegar a algo ou a alguém como necessidade de sobrevivência. O bebê, quando nasce, não tem, como nenhum outro mamífero, a capacidade de cuidar de si mesmo, de alimentar-se, de moverse, etc. Dessa forma, pode-se considerar Bowlby (1982), quando trata da relevância da formação de vínculos. Segundo ele, essa é uma capacidade tão típica do homem quanto qualquer outra capacidade fisiológica vital, ou seja, inerente a ele com valor de sobrevivência. Para isso, o indivíduo manifesta um tipo de comportamento definido por Bowlby (1980) como comportamento de apego, que constitui a busca e a manutenção da proximidade de um outro indivíduo, geralmente a mãe ou o pai, se ele estiver envolvido nesse processo.

Ressalta-se também que a questão da sobrevivência também está relacionada à necessidade de afeto da criança ou do bebê de se sentir inserido em um mundo, de certo modo, e de notar que há alguém que o percebe. Winnicott (1985) descreve o momento da amamentação bem como os cuidados básicos que a mãe deve ter para com 
o filho. A experiência do seio, por exemplo, possibilita o contato, a satisfação e o prazer ao bebê, se for vivenciada de modo calmo, positivo e acolhedor pela figura materna. $\mathrm{O}$ sentimento de acolhimento, de cuidado, de segurança e de provisão, por parte da criança, configuram elementos fundamentais que emergem da relação pais e filho, e, como Bowlby (1982) ressalta, o comportamento de apego carrega em si o sentimento mais forte do que qualquer outro comportamento que a criança possa expressar. As figuras objeto desse sentimento são amadas e muito esperadas. A presença da figura materna (Winnicott), ou da figura principal de apego (Bowlby), como aqui se pode considerar, traz segurança e tranquilidade para a criança, enquanto a sua falta, entendida como uma ameaça de perda, pode gerar angústia, ansiedade e, no caso de uma perda de fato, um sentimento de profunda tristeza.

Se, por um lado, tem-se a vinculação afetiva como fenômeno preponderante na vida da criança, por outro, tem-se a separação, que constitui a perda do objeto de afeto e que é tão inerente ao indivíduo quanto àquela. Sobre o estabelecimento de vínculos, Ballone (2003) ressalta a importância da existência de uma pessoa que esteja comprometida em suprir as necessidades do bebê, caso contrário, ele não conseguirá estabelecer uma relação eficiente com o mundo externo. Bowlby (1980) faz referência à angústia de separação, que configura uma situação na qual a criança não se encontra na presença da figura principal de apego, e, a partir dela, emergem sentimentos como ansiedade e medo. Contudo, esses são sentimentos que poderão dar o sentido de auto-proteção, autoconservação e expansão para a criança em situações típicas do desenvolvimento infantil, como a separação da criança na relação mãe-bebê e o seu posterior crescimento como adulto.
No entanto, na questão da institucionalização, o que se questiona é quantas crianças tiveram ou estão tendo a possibilidade de vivenciar esse desenvolvimento, essa transição dos vínculos afetivos de maneira adequada, sem rupturas bruscas e com elaborações psíquicas? Ballone (2003) sugere que há uma negligência precoce vivida pela criança em uma fase crítica de sua vinculação e que pode ter prejuízos permanentes ou importantes em sua vida adulta, e ressalta não só aspectos psicológicos bem como fisiológicos, embora o estudo quanto a esses fatores ainda seja incipiente. Para ele, tal fato não estaria ligado apenas a crianças de orfanato, mas igualmente àquelas que sofrem separações dos pais, ou mesmo àquelas que, apesar de viverem em seus lares, são abandonadas por negligência ou omissão. Como consequência dessa situação de ruptura precária de vínculos, Ballone (2003) coloca que:

Uma das seqüelas da criança de orfanato diz respeito à graduação ou nível em que ela estabelece vínculos com outras pessoas. Alguns, por padrão de vínculo inseguro, costumam ser exageradamente amigáveis com todos que se aproximam, como se tentassem atrair a companhia de alguém que lhes desse mais segurança; outros, ao contrário, parecem evitar qualquer aproximação mais calorosa, como se tivessem medo da decepção. Essas crianças parece que sentem a falta de pessoas particularmente sintonizadas com elas... (p. 12)

A proposta trazida por esse autor em relação à vinculação afetiva dessas crianças, não somente com a instituição mas também com os futuros pais adotivos, a futura família, remete a Hughes (1999 como citado em Ballone, 2003), que recomenda que os problemas de vínculo sejam previamente estudados e detalhados para, a partir desse conhecimento, elaborar condutas junto aos pais adotivos, de acordo com a demanda trazida pelos mesmos, relacionada com o processo de vinculação. 
Esse é apenas um exemplo que se propõe acerca da reflexão sobre vínculos entre pais e crianças adotivas. A adoção, portanto, caracteriza-se como um tema complexo e difícil, pois "inclui questões relacionadas a perdas e sofrimentos, falhas sociais e narcísicas" (Tabajaski \& Chaves, 1997, p. 1); assim, uma discussão ampla sobre esse tema remete a questões que têm início no âmbito social, como o preconceito racial e a discriminação, e vão até as necessidades individuais mais íntimas da construção do sujeito, a exemplo dos modelos de família e dos ideais parentais produzidos subjetivamente.

Já no âmbito legal, a Constituição Federal estabeleceu, desde outubro de 1998, que não há diferença entre filhos nascidos dentro ou fora do casamento e entre filhos legítimos (naturais) e adotivos. Os filhos adotivos eram mais conhecidos no Brasil como filhos de criação, contudo, essa denominação tem dado lugar a filho nascido do coração, ou seja, os filhos adotados terão a condição de filhos, com iguais deveres e direitos dos filhos naturais. Ainda de acordo com as disposições da Constituição Federal, do Estatuto da Criança e do Adolescente (1990) e do Código Civil (2003), podem adotar as pessoas maiores de dezoito (18) anos, independentemente de seu estado civil, contanto que o adotante seja dezesseis (16) anos mais velho que o adotado. As pessoas que são casadas ou que vivem juntas podem adotar em conjunto, desde que uma delas seja maior de 18 anos e comprove que tem uma união estável. Pessoas divorciadas ou separadas judicialmente podem adotar em conjunto, desde que o estágio de convivência com o adotado tenha sido iniciado na constância da união conjugal e que ambos estejam de acordo quanto à guarda da criança e às visitas. Para os estrangeiros que não residem no País e desejam adotar uma criança ou adolescente, é necessário que possuam um Laudo de Habilitação da
Comissão Estadual Judiciária de Adoção do Estado em que desejam ser inscritos. Esse laudo é expedido pela Comissão Estadual Judiciária de Adoção Internacional para instrução do processo judicial de adoção, após o exame de aptidão e capacidade do pretendente e verificação de que a validade jurídica da adoção seja assegurada no país de origem do interessado, resguardados os direitos do adotando segundo a legislação brasileira.

Não podem adotar os parentes ascendentes do adotante, como avós e bisavós, e nem os parentes descendentes, como filhos, netos e irmãos, contudo, tios e primos podem fazêlo; não é permitida a adoção em conjunto por pessoas do mesmo sexo, pois, para tal, é preciso que sejam casados legalmente ou que vivam em união estável. A legalidade desse tipo de adoção tem sido discutida atualmente, tendo em vista as dificuldades em se conseguir a efetivação da adoção de crianças mais velhas e o desejo manifesto cada vez maior desses casais em adotar uma criança. Não entramos, no entanto, por ora, no mérito da questão.

A adoção é possível para criança e/ou adolescente com, no máximo, dezoito anos à data do pedido de adoção, exceto se já estiver sob a guarda ou a tutela dos adotantes. As pessoas acima de dezoito anos podem ser adotadas, mas seus direitos não serão tão amplos quanto aqueles concedidos pelo Estatuto da Criança e do Adolescente. Os adolescentes maiores de doze (12) anos devem, obrigatoriamente, dar consentimento para serem adotados. O filho adotivo tem garantidos os mesmos direitos e deveres de um filho natural, como foi anteriormente exposto, e, com isso, Ihe é vedado qualquer tipo de vínculo jurídico com os pais e parentes biológicos, salvo os impedimentos matrimoniais para que se evitem os casamentos entre irmãos ou de filhos com pais (Cartilha da Adoção: ${ }^{2}$ - Vara da Infância e da Juventude do Recife, 2004). 
Existem formas diversas de se concretizar uma adoção, como, por exemplo, a adoção com prévio cadastramento dos adotantes, incluindo aqui a adoção internacional, através de todos os trâmites legais, a adoção unilateral, quando um dos cônjuges ou conviventes adota o filho do outro, a adoção com adesão expressa dos genitores, a adoção cumulada com decretação de perda do poder familiar e a adoção post-mortem, quando o pretendente falece durante o processo de adoção.

Vale salientar que são esses os tipos de adoções legais que podem ocorrer. No Brasil, é comum a adoção à brasileira, como é conhecida. Esta ocorre quando não é realizado o processo legal de adoção, e a pessoa que pretende adotar registra em cartório um filho que não é seu, mas assume-o como tal, o que constitui prática criminosa, porém bastante recorrente.

Outro tipo de prática também muito comum no Brasil é a adoção por criação, como ressaltam Fu e Matarazzo em um estudo no qual abordam esse tema. Segundo as autoras, devido à constituição sociocultural no Brasil, algumas das famílias que têm filhos adotivos não fazem muita distinção entre os filhos adotados legalmente e os chamados filhos de criação, ou seja, a adoção sem o registro judicial. Dentro dessa distinção, as autoras ressaltam que há ainda dois tipos de adoção, denominadas adoção intrafamiliar e adoção extrafamiliar, definidas desta forma:

Adoção intrafamiliar (AIF): aquela em que as crianças passaram para os cuidados de algum familiar em primeiro grau (pais ou irmãos) de seus pais biológicos por um período superior a 12 meses, sendo ou não a adoção realizada por procedimento legal de adoção, tutela ou guarda.

Adoção extrafamiliar (AEF): aquela em que as crianças passaram para os cuidados de pessoas sem relação de parentesco com seus pais biológicos por um período superior a 12 meses, sendo ou não a adoção estabelecida por processo legal de adoção, tutela ou guarda. (Fu \& Matarazzo, 2001, p. 3)

Dessa forma, são apresentadas algumas modalidades de adoção que não possuem efeito judicial ou legal, mas que são recorrentes no contexto sociohistórico-cultural brasileiro. Segundo Fu e Matarazzo, o Brasil conta com um histórico de famílias numerosas quanto aos filhos, de forma que se passam as gerações e, na falta dos pais biológicos, outros membros da família, como irmãos, tios ou pessoas próximas, mas sem ligação de parentesco consanguíneo, criam e educam as crianças como se fossem seus filhos; logo, essa prática constitui, em linhas gerais, uma prática de adoção, conforme o entendimento das autoras acima referidas, haja vista que tais adotantes se tornaram responsáveis, seja por processo legal de adoção ou não, pela educação, orientação e bem-estar daquela criança. Nesses casos, é importante salientar que, conforme as disposições do art. 42, $\S 10$, não podem adotar, legalmente, os ascendentes (como avós e bisavós) e os irmãos do adotando (ECA, 1990, p. 19).

\section{Os abrigos}

Os abrigos surgiram ao longo da história do Brasil como a alternativa mais adequada para garantir a proteção de crianças em situações de abandono. Santos (2000) elaborou uma coletânea geral de alguns dados históricos sobre a criação dessas instituições de recolhimento (p. 79) e sobre algumas transformações por que passaram no Brasil e que serão destacadas aqui como forma de situar o leitor na caracterização histórica dos abrigos.

Inicialmente, essas instituições foram organizadas pelas classes mais privilegiadas da sociedade, que viam na prática da caridade uma forma de garantir a salvação de sua alma. 
Segundo

Marcílio (1998),

o abandono

de filhos é uma

prática bem

antiga que varia apenas nas motivações, de circunstâncias,

de causas e de atitudes, em relação à prática do abandono ao longo do tempo.
No século XIX, aproximadamente, surgem as primeiras instituições de abrigo e de amparo à criança exposta. Somente no início do século XX é que surgem os primeiros códigos de leis direcionados à infância desvalida.

Segundo Marcílio (1998), o abandono de filhos é uma prática bem antiga que varia apenas nas motivações, de circunstâncias, de causas e de atitudes, em relação à prática do abandono ao longo do tempo. Além disso, a autora ressalta que, salvo algumas exceções, esse ato nunca foi condenado, nem pelo Estado, nem pela sociedade e nem pela Igreja, antes da Declaração Universal dos Direitos da Criança (1959). Tal prática era aceita e até justificada, porque evitaria outros males, como o infanticídio, o aborto e a desonra pública, além de contribuir, no âmbito econômico em família, como sistema de herança igualitário para o controle do tamanho da família e da fragmentação da propriedade paterna.

A autora relata que o Brasil e a Europa passaram por fases semelhantes na assistência à infância desamparada, fases essas que dominaram determinados períodos históricos, mas não deixaram de coexistir elementos de uma ou de outra fase em tais períodos. A primeira fase era denominada assistência caritativa e tinha um caráter individual, na qual as crianças abandonadas eram abrigadas pelos indivíduos em suas próprias casas e criadas por eles, o que possibilitava a essas pessoas praticar a compaixão, a caridade para poder salvar sua alma. Contudo, podemos notar que esse sentido de caridade ainda se mantém forte na burguesia, tendo como base uma moral cristã, que reforça a ideia de expiação de culpas, demonstrando um lado humanitário e altruísta e, ao mesmo tempo, contribuindo para a manutenção do status quo.

No Brasil, as primeiras instituições de abrigo à criança surgiram a partir do século
XVIII, seguindo o modelo de abrigos da Misericórdia, de Lisboa, na qual havia rodas expostas e recolhimento de meninas pobres, dentro do padrão caritativo assistencial, no qual ainda não se tinha noção do abandono como problema social grave.

A segunda fase é marcada por uma filantropia científica, e surge, no Brasil, no século XIX, seguindo o modelo de países europeus. Foi uma fase marcada pela filosofia iluminista e liberal, reforçada pela industrialização e pela urbanização européias. No Brasil, em menor grau que na Europa, a questão do abandono de crianças ganhou uma dimensão tão grande que passou a fazer com que o governo e a sociedade criassem instituições e políticas públicas que pudessem arcar com esse agora significativo problema social. No mesmo registro, Santos (2000) discorre acerca de um grande massacre havido, com muitas mortes de bebês nessas instituições, o que provocou forte reação no sentido de se diminuir as taxas de mortalidade, recorrendo à Medicina, enfim à ciência, na produção de conhecimento que pudesse embasar uma prática centrada não apenas na salvação da alma mas também no cuidado com o corpo. A saúde e a educação surgem, então, como prioridades das políticas públicas. Além disso, é dada maior importância à família, à relação mãe-bebê como ponto fundamental para o desenvolvimento adequado e equilibrado da criança. Ainda em relação a essa fase, o ato do abandono passa a ser condenado, e a criança passa a ser valorizada e vista como o futuro e a riqueza da nação.

É então posta em questão a representação que se coloca, no final do século XVIII, na França, e no século XIX, no Brasil, do valor econômico, de mercado, que se atribui à criança como potência econômica. Esta teria não apenas o sentido de força braçal produtiva mas também o de reforço para as forças militares, o que significaria que toda perda humana seria um prejuízo para o Estado. 
A terceira fase é caracterizada pela assistência e proteção à infância, na qual o Estado começa a assumir a responsabilidade pela infância necessitada (Santos, 2000, p. 82), após uma Carta dos Direitos Universais da Criança, criada em 1924 e aperfeiçoada em 1959 pela Liga das Nações Unidas, depois da Primeira Guerra Mundial. No Brasil, são instituídas políticas públicas para a população pobre. Em 1927, é criado o Código de Menores, dirigido à infância desvalida e desviante. $\mathrm{O}$ instituto da adoção é regulamentado no Código Civil, em 1916, e depois nos Códigos de Menores de 1927 e 1979, e terá seu caráter restritivo superado em 1990, com a criação do Estatuto da Criança e do Adolescente.

Na época da República Velha, a visão que se tinha era a de que o problema social era caso de polícia, por isso o caráter correcionalrepressivo que era imposto a esse público, a infância e a adolescência desvalidas, que era visto como uma ameaça à sociedade. $\mathrm{Na}$ década de 1960 do século passado, foram criadas as instituições totais de abrigo, que visavam à proteção, educação e capacitação da infância e da adolescência delinquentes. Nelas, o indivíduo era isolado até a sua regeneração, seria treinado para ser devolvido à sociedade, podendo então ser mais útil e dócil a essa mesma sociedade. O Serviço de Assistência ao Menor, do Ministério da Justiça, regia suas ações impregnado por essa visão.

Em 1964, para reverter tal situação, é criada a Política Nacional do Bem-Estar do Menor. Além disso, são criadas a Funabem, órgão federal normativo, e as Febem (Fundação do Bem-Estar do Menor), estaduais, órgãos executores.

O enfoque, então, passa de correcionalrepressivo para assistencialista, só que embasado em conhecimentos científicos, o que o diferencia da primeira fase. A representação que se tem do adolescente e/ou da criança, nesse momento histórico (1964), é a de um de indivíduo repleto de carências biopsicossociais, para o qual passaram a ser criados vários centros de atendimento especializado na tentativa de suprir ou minimizar suas necessidades.

Contudo, é no final da década de 1970 do século passado, com o processo de abertura democrática, que se inicia um movimento de educação progressista, com a mobilização de educadores e trabalhadores da área. Logo, "o menor deixa de ser visto como um 'feixe de carências' e passa a ser percebido como sujeito de sua história e com potencial aberto para o futuro" (Santos, 2000, p. 83).

Vale ressaltar a importância que a criação do Estatuto da Criança e do Adolescente teve para a realidade dessas crianças, representando, "em nosso país, uma verdadeira revolução na forma de conceber e tratar as questões da infância e da juventude" (Santos, 2000, p. 76). Apesar disso, muitas vezes, a prática não corresponde ao que está no papel. Para que as crianças tenham assegurados seus direitos, com base no cumprimento das normas e princípios do ECA, não basta considerar que o Estatuto exista, mas é preciso lê-lo de maneira adequada, construindo uma reflexão crítica e transformadora em relação à postura e à abordagem da prática profissional historicamente construída e instituída na área da criança e do adolescente, especialmente no plano do Poder Judiciário (Santos, 2000). Essa autora chama ainda a atenção para as leituras equivocadas que têm sido feitas em relação ao ECA, nas quais se confunde "proteção integral, respeito à condição da criança como pessoa em desenvolvimento, com impunidade".

Ribeiro e Ciampone (2002) consideram que a proteção à infância e à adolescência envolve vários setores da sociedade brasileira, desde a população até os governantes, na elaboração 
de seus projetos e investimentos. Para elas, o problema da criança em situação de rua é considerado um fenômeno social originado da história e da política econômica do Brasil, que remete a uma realidade social que tem em seu cerne um desenvolvimento econômico desigual, com riquezas mal distribuídas e recursos mal utilizados, além de uma falta de prioridade marcante nas políticas e nos orçamentos públicos para essa população de baixa renda. Para tanto, ao Estado e à sociedade civil cabem conjuntamente a resolução desse problema. É fato que grande parte das crianças que vivem em abrigos já passaram por situações de negligência e abandono marcantes, agravados, ou muitas vezes decorrentes de uma situação socioeconômica instável, na qual os pais ou responsáveis alegam não ter condições para ficar com as crianças.

Segundo Soares (2005), os dados de uma pesquisa realizada pela AASPTJ-SP e SAS revelaram algumas causas que levam crianças ao abrigo. De acordo com a pesquisa, 22\% das crianças são levadas devido ao abandono ou à negligência, 19\%, devido a problemas relacionados à saúde e a condições sociais desfavoráveis, $10 \%$, a violência física na família, 10\%, devido ao uso de drogas/ alcoolismo pelo pai e/ou mãe, 7\%, de entrega das crianças a terceiros que não puderam cuidar delas, $7 \%$, devido à morte do pai e/ ou mãe, $6 \%$ são crianças em situação de rua, $5 \%$, devido a problemas mentais de pai e/ou mãe, 4\%, à prisão do pai e/ou mãe e $10 \%$, a outras causas não especificadas. A família existe, mas, na maioria dos casos, não possui condições para manter junto de si a criança. Como observa Guará em relação à pesquisa acima citada, "não existem políticas públicas de apoio a famílias sem condições mínimas de proteger suas crianças". Além da falta de medidas preventivas, também faltam medidas de reabilitação, que permitiriam melhor estruturação familiar para que as crianças pudessem retornar para sua família de origem.
Para Mascarenhas e Dupas (2001), a família

é considerada o ponto fundamental de ação para qualquer solução duradoura e persistente do problema da criança e do adolescente, mas essa ação apenas mudará se ocorrerem mudanças na estrutura do modelo de desenvolvimento do País. Como tais transformações não têm acontecido, esse problema vem se agravando ainda mais com o aumento dos índices de desemprego, que piora a situação de desestruturação familiar e leva, muitas vezes, à institucionalização de crianças e adolescentes.

Ribeiro e Ciampone (2002) chamam a atenção para a participação da sociedade civil e do Estado na implementação de medidas como a criação de organizações não-governamentais e do estabelecimento de prioridades nos orçamentos nacional e regional nas ações em favor da criança em situação de risco. Os autores ressaltam, contudo, que essa luta não obterá resultados muito animadores se não houver maior engajamento nas muitas possibilidades de atuação em prol da criança em situação de exclusão social, ou seja, nas situações em que o indivíduo não possui qualquer acesso a bens de consumo e quando esse mesmo indivíduo se torna inútil no que tange ao movimento do capital. Como ressalta Santos (2001), o aumento das desigualdades de renda atinge, especialmente, as classes sociais marginalizadas que vivem nos grandes centros urbanos, os trabalhadores sem terra e os desempregados do meio rural. Desse modo, as contradições de classe, os antagonismos, as hierarquias e as diversidades sociais se reproduzem na sociedade dominada pelo capitalismo.

Santos (2000) revela outros fatores que também estariam na gênese desse fenômeno de exclusão. Tais fatores estão ligados à dimensão individual e subjetiva e "dizem respeito às histórias singulares de vida, às escolhas, desejos e interesses pessoais dos 
genitores" (p. 83), que representariam o desejo real dos pais em estar com a criança, porém que, na impossibilidade de fazê-lo, o que é considerado até mesmo na questão originária do fenômeno, são obrigados a abandonar os próprios filhos. A relação mãe-bebê, na dimensão subjetiva do desejo, também é um exemplo a ser considerado, pois trata das motivações implícitas nessa relação que tornou inviável a permanência da criança junto à mãe, e que pode ser avaliada nas motivações dos pais em relação ao bebê. Esse é um ponto relevante a ser considerado, no sentido de que possibilita a nossa reflexão, como profissionais da área, de que existem outros fatores relativos à questão do desejo e do interesse dos pais quanto à criança na questão social.

Desse modo, não se trata apenas de melhoria das condições dos abrigos, nos quais as crianças abandonadas estão inseridas - aliás, o enfoque das instituições é de que sejam provisórios - mas também de se considerar a necessidade e a possibilidade de essas crianças se encontrarem no seio de uma família que se responsabilize por elas. Altoé (1988) ressalta as condições e a pobreza afetiva em que se encontram as crianças que ainda vivem em instituições totais, como os abrigos, e afirma que a criança institucionalizada é o modelo que resulta da ausência de uma vinculação afetiva estável e constante e dos prejuízos oriundos de um ambiente opressivo, empobrecido e limitante ao desenvolvimento infantil. Santos considera ainda que:

Os que conhecem de perto as instituições de abrigo e não se limitam apenas a ouvir o depoimento dos que habitam esse universo (...) sabem que, para essas crianças, não há abrigos de tipo ideal. No máximo, há alguns com condições e relações mais humanas, porém, certamente, sem recursos e aptidão para preencher suas lacunas afetivas/subjetivas e existenciais. Por outro lado, volto a enfatizar, não se trata apenas dos evidentes limites da realidade presente vivida por essas crianças/adolescentes, mas do seu futuro em uma sociedade cada vez mais excludente e seletiva. (Santos, 2000, p. 85)

Em outras palavras, de alguma forma, estar inserido em um abrigo adequado ou na própria sociedade excludente e marginalizante representa riscos para a criança, a primeira alternativa, devido à impossibilidade de uma vinculação afetiva adequada, e a segunda, devido à dificuldade de a criança se inserir em uma estrutura de capital cada vez mais exigente e que segrega quem a ela não se submeta ou não tenha condições de se submeter. Dessa maneira, reforça-se a ideia da prioridade de garantir à criança as condições básicas necessárias ao seu pleno desenvolvimento, imbricada na prática dos profissionais que trabalham nessa área bem como na sociedade em geral.

\section{Método}

Diante do objetivo geral a que se propôs este trabalho, o de compreender o modo de vivenciar a afetividade em crianças institucionalizadas à espera de adoção, foi utilizada uma metodologia que pudesse alcançar uma dimensão compreensiva do fenômeno. Tal proceder é caracterizado através do método qualitativo. Alves-Mazzoti (1999) enfatiza a metodologia qualitativa, e ressalta que não existe modelo-padrão para se construir um conhecimento confiável, mas que existem modelos adequados e inadequados para se investigar.

Esse método objetivou analisar e compreender o fenômeno que aparece em sua multiplicidade e complexidade; parte do singular, analisando o que há de próprio no fenômeno, considerando-o como aparece e, principalmente, com as qualidades que apresenta. No presente trabalho, foi utilizado um método que teve 
o intuito de realizar uma interpretação do fenômeno, caracterizando-o com base em uma análise que parte do que é dado por este e correlaciona os dados com a teoria, que constitui a sustentação do método. $\mathrm{O}$ método qualitativo oferece a possibilidade de maior envolvimento entre pesquisador e objeto pesquisado, como será descrito com mais detalhes posteriormente, visto que o método fenomenológico, proposto para este estudo, sugere o envolvimento existencial como condição fundamental para sua realização (Forghieri, 1993). Outra característica relevante do método qualitativo é a possibilidade de vários enfoques; por se tratar de um método interpretativo, ele permite que o mesmo tema seja abordado sob diversos prismas.

O estudo foi realizado sob a perspectiva da abordagem fenomenológica existencial, que busca investigar a vivência da vinculação afetiva através do método fenomenológico. "A experiência do vivido é significada pelo sujeito e está relacionada com a sua própria forma de existir" (Forghieri, 1993, p. 58), isto é, à medida que o sujeito vivencia as situações em sua existência, essa vivência se torna parte de sua elaboração psíquica e configura sua forma de estar no mundo e de se relacionar com o outro. A experiência vivida, que se refere à manifestação da afetividade por parte das crianças, será apresentada por meio do critério de análise de três etapas que compreendem o método fenomenológico: descrição, redução e interpretação.

É um critério de análise porque consiste, primeiramente, numa separação de partes de um todo e numa demarcação de unidades de sentido do texto original (descrição). Mas é também uma síntese, porque agrupa as partes separadas (redução) em novas partes (tipologias, categorias) que são acrescentadas ao todo (interpretação). (Gomes, 1998, p. 52)
Inicialmente, na descrição, o pesquisador busca descrever e refletir sobre o fenômeno que emergiu, a partir do que foi manifestado pelo sujeito, adentrando em sua vivência. Nessa fase, o pesquisador procura analisar e separar as partes que surgem do todo e que se caracterizam por unidades de sentido distintas dentro do discurso produzido pelo sujeito pesquisado, no caso, as crianças e sua afetividade. Já a redução fenomenológica pressupõe o distanciamento do mundo exterior, o colocar entre parênteses e focar a consciência do objeto percebido para o sujeito que o percebe, que, no caso, se traduz pela síntese das categorias percebidas como emergentes do fenômeno do vínculo afetivo produzidas pela criança e que foram separadas pelo pesquisador. A fase posterior, de interpretação, caracteriza-se por um retorno elaborado ao todo, em que se ressalta o que há de significativo para o sujeito em uma atitude dialógica entre pesquisador e pesquisado, através da intersubjetividade de indivíduos que compartilham de um mesmo mundo, objetivando a compreensão de como o fenômeno ocorre nesse outro (Gomes, 1998).

Forghieri descreve dois momentos interrelacionados e reversíveis que constituem a redução fenomenológica na Psicologia: o envolvimento existencial e o distanciamento reflexivo. O pesquisador, voltando-se para a experiência do sujeito que deseja investigar, abstém-se dos conhecimentos anteriormente adquiridos sobre o tema que pretende analisar. Desse modo, ele estará aberto para adentrar, de modo espontâneo e experiencial, a vivência do sujeito, de maneira imediata ao fenômeno, deixando "surgir a intuição, percepção, sentimentos e sensações que brotam numa totalidade, proporcionandoIhe uma compreensão global, intuitiva, préreflexiva, dessa vivência"/ç (Forghieri, 1993, p. 60).

O distanciamento reflexivo é caracterizado como um momento em que o pesquisador 
se coloca a certa distância dessa vivência, procurando "refletir sobre essa sua compreensão e tentar captar e enunciar, descritivamente, o seu sentido ou o significado daquela vivência..." (p.60) para o sujeito que a experiencia. Forghieri ressalta ainda o distanciamento não definitivo da experiência do outro no sentido de que o pesquisador deve se colocar em ligação com o sujeito e com sua vivência, podendo retornar a ela sempre que necessário, a fim de obter uma descrição a mais fidedigna possível daquela história de vida.

Como coloca Moreira (2004, p. 8),

O mais importante para a pesquisa fenomenológica nesse enfoque, seja qual for o instrumento utilizado, será a priorização da experiência. Partese do pressuposto metodológico de que o sujeito-colaborador sabe dessa experiência, já que a vivenciou. O pesquisador se propõe, portanto, a aprender com quem já viveu ou vive a experiência sobre a qual ele quer aprimorar seus conhecimentos.

Nesse sentido, sujeito e pesquisador vivenciam a possibilidade de produzir conhecimento a partir do vivido. Para tanto, Moreira sugere que a descrição do fenômeno vivido deve ser exaustiva, proporcionando ao sujeito-colaborador dizer de diversas maneiras, várias vezes, como é para ele vivenciar aquela experiência, o que está em foco na investigação da pesquisa. É importante ressaltar que, dessa maneira, nem pesquisador nem sujeito-colaborador podem ser vistos como elementos neutros.

O modelo metodológico utilizado para esta pesquisa foi embasado em um método descrito por Moreira. A autora propõe um método de análise, na perspectiva fenomenológica descritiva, que se compõe de três momentos, e que resultou no que ela denomina análise fenomenológica mundana. Os momentos são assim divididos: 1) divisão do texto nativo, que se caracteriza como o momento inicial da pesquisa, a descrição. $\mathrm{O}$ texto nativo compreende o que emergiu como fenômeno, o que foi produzido pelo sujeito pesquisado, a partir dos instrumentos utilizados (Moreira, 2004). No caso das entrevistas, constitui sua transcrição literal, contendo a descrição da mesma tal qual ela ocorreu. No caso dos demais instrumentos, constitui uma descrição do conteúdo realizada a partir do que foi manifestado. 2) Análise descritiva do significado ou da chamada articulação de sentido emergente da descrição: caracteriza-se por um olhar da transcrição que busca o significado da experiência vivida pelos sujeitos através do próprio fenômeno emergente. 3) Saindo dos parênteses, momento em que o pesquisador retorna ao seu objeto de estudo, posto em parênteses nos momentos anteriores, buscando relacionar as categorias ou unidades de sentido ao todo que compreende o sujeito. Como ressalta Gomes (1998), o método fenomenológico focaliza seu objeto de estudo de forma global, em que há o acta (o que é feito), o data (o que é dado) e o capta (o que é tomado). No presente estudo, tem-se os relatos das crianças e os desenhos (acta), obtidos por meio das entrevistas e das observações durante as brincadeiras (data) na forma como foram interpretadas pelos pesquisadores (capta). É importante salientar, no entanto, que a percepção dos pesquisadores, na compreensão fenomenológica, não deve ser tomada como expressão de uma subjetividade, porque ela apenas tem sentido como produção compartilhada, a partir da intersubjetividade, no contexto de relações interpessoais. Dessa maneira, além de se poder perceber um fenômeno sob variados prismas, o sujeito colaborador pode dizer de si, e, a partir disso, contribuir para a construção de um conhecimento advindo de sua experiência própria e única.

Além das informações obtidas por meio do relato e da observação dos sujeitos, realizou- 
se uma pesquisa documental nos prontuários dos sujeitos pesquisados resguardados na própria instituição com o intuito de se obter subsídios acerca da história de vida das crianças, como complemento, e para fins de análise junto aos outros dados.

\section{A instituição}

A pesquisa foi realizada em um abrigo, vinculado a um órgão estatal. Foi criado em 1975, e, em 1994, passou a atender as diretrizes legais, tendo suas ações regidas pelos princípios expressos no art. 92 do Estatuto da Criança e do Adolescente no que diz respeito à: preservação dos vínculos familiares, integração em família substituta, atendimento personalizado e em pequenos grupos, desenvolvimento de atividades em regime de coeducação, não desmembramento de grupos de irmãos, impedimento, sempre que possível, da transferência para outras entidades de abrigamento, participação na vida da comunidade local, preparação gradativa para o desligamento e participação de pessoas da comunidade no processo educativo. $\mathrm{O}$ dirigente do abrigo é equiparado ao guardião, para efeitos de direito da criança. O abrigo se destina a atender crianças e adolescentes de ambos os sexos, com faixa etária de admissão de 0 a 6 anos, que se encontram em situação de ameaça ou violação de direitos, na condição de abandonados ou temporariamente impossibilitados de permanecer com a família.

São realizados três tipos de atividades junto às crianças: manutenção de vínculos, que consiste na relação entre a criança e a família de origem, mediada pela instituição, através da equipe, esgotados os recursos para o retorno da criança à família; lar substituto ou lar acolhedor, que se caracteriza pelo encaminhamento da criança para outro lar, tendo a criança o direito ao convívio com uma família; esta recebe uma ajuda de custo compatível com os gastos da criança e tem o compromisso de acolhê-la. Essa família é previamente inscrita, e com ela a criança passa a residir em caráter temporário ou permanente até que sejam dados os devidos encaminhamentos de retorno ao lar ou a possível adoção, no caso de crianças abandonadas, e o Projeto Especial, que acolhe crianças com deficiências. A adoção propriamente dita, ou abrigo, acolhe as crianças que estão à espera de uma nova família, pois não têm mais o contato com a família de origem. Vale ressaltar que o procedimento de adoção não é realizado pela instituição, pois esta tem a função de abrigar as crianças em situação de risco e viabilizar essa relação entre o Juizado da Infância e da Juventude, responsável pelo procedimento de adoção.

A instituição utiliza recursos da comunidade, procurando integrar ações de atendimento às crianças em hospitais, escolas, igrejas, centros comunitários, etc. Internamente, atende a criança nas áreas de saúde preventiva e terapêutica e desenvolve atividades pedagógicas e recreativas. Lá estão presentes profissionais como pedagogos, assistentes sociais, enfermeiras, terapeuta ocupacional, psicóloga e economista doméstico. As atendentes não necessitam de formação específica para trabalhar com as crianças, e muitas delas trabalham com o título de servidoras públicas, visto que a instituição é mantida pelo Governo do Estado.

Segundo a assistente social da instituição, o perfil mais requisitado para adoção é o de crianças com até três anos de idade, de cor clara e do sexo feminino. Ela ressalta, também, o grande número de adoções por estrangeiros e declara haver um bom retorno dessas famílias em relação aos cuidados com as crianças adotadas. De acordo com dados da Secretaria de Ação Social do Estado do Ceará (SAS - CE - Projeto Família 
Acolhedora), no período de janeiro a abril de 2006, estavam abrigadas 83 crianças, e 90 se encontravam em lares substitutos, perfazendo um total de 173 crianças atendidas no referido período. Ocorreram 2 reintegrações à família de origem e 9 crianças foram encaminhadas para adoção.

\section{Descrição dos sujeitos}

Os sujeitos da pesquisa foram quatro (dois meninos e duas meninas), entre 6 e 9 anos de idade. A margem de idade considerada se deveu à dimensão pela qual se optou realizar a análise: somente crianças que estão à espera de adoção, excluindo aquelas que mantêm algum tipo de vínculo com famílias fora da instituição, compreendidas nas modalidades de lar substituto e de manutenção de vínculos, já anteriormente descritos, e pela possibilidade de expressar conteúdos de sua vivência através de brincadeiras e das entrevistas que foram realizadas com essa finalidade. Para efeito de preservação da identidade dos sujeitos envolvidos na pesquisa, foram utilizados nomes fictícios.

\section{Instrumentos}

Foram utilizados como instrumentos da pesquisa: entrevista semiestruturada, organizada em tópicos, como norteadora do diálogo, sem caráter diretivo, que possibilitou uma vinculação mínima entre pesquisadores e colaboradores e com sequência flexível (a saber: estado emocional da criança, pessoas preferidas pela criança na instituição, brincadeiras preferidas, percepção da criança em relação ao seu abrigamento, desafetos da criança na instituição); observações participantes em brincadeiras diversas (exemplo: jogo de bola, esconde-esconde, trabalhos em grupo e momentos de atividade livre) com as crianças e observações a partir de desenho livre. Tais observações tiveram a finalidade de fornecer subsídios sobre o brincar da criança, buscando ressaltar elementos que remetessem à sua afetividade e à sua vinculação, seja com as assistentes, seja com outras crianças.

\section{Resultados}

Após o momento descrito acima, de coleta de dados, foi realizado o processo de análise desses dados. Foi utilizada como referência a metodologia proposta por Moreira (2004), descrita anteriormente, contendo os passos a serem seguidos: transcrição do texto nativo, articulação de sentido e saindo dos parênteses, nos quais se analisou o sentido da vinculação afetiva para algumas crianças da instituição. Foram considerados, para efeito de análise, os relatos e os desenhos das quatro crianças citadas anteriormente, que foram submetidas aos instrumentos propostos. A partir dos relatos contemplados nas análises, puderam ser destacadas algumas categorias em que foi observada alguma referência à vinculação afetiva. Os resultados referidos a seguir foram formulados a partir da compilação dos dados e da análise do texto nativo, da articulação de sentido, culminando na interpretação que é caracterizada pelo momento saindo dos parênteses, como proposto na metodologia. Seguem abaixo as categorias que se fizeram pertinentes no conteúdo explicitado pelas crianças e que estão exemplificadas com trechos do relato delas obtidos nas observações e/ou durante as entrevistas.

O vínculo com a instituição é descrito como algo bom, agradável, em que as crianças atribuíram um valor de consideração pelo ambiente onde se encontram:

$$
\begin{aligned}
& \text { - "Eu gosto daqui, tia". (Jorge, } 6 \text { anos) } \\
& \text { - "Eu gosto daqui, tia, eu não queria sair } \\
& \text { daqui, não... (Natália, } 9 \text { anos) }
\end{aligned}
$$

A relação com as atendentes, ou cuidadoras, foi descrita pelas crianças como uma vinculação afetiva, variando de uma criança 
para outra. Geralmente, algumas figuras da instituição foram descritas como pessoas a quem as crianças atribuem, seja em uma lembrança, seja em um desenho, uma importância significativa. Sendo livre o tema do desenho, pôde ser observada a questão da vinculação afetiva, que se apresentou como fenômeno emergente, e, quando afirmativo, foram verificadas as relações e os significados que as crianças puderam estabelecer acerca dos mesmos. Ambos os relatos abaixo foram manifestados com base em um desenho livre que as crianças construíram e que faziam referência às cuidadoras do abrigo:

- "...Essa é a enfermeira, outra enfermeira, tu, tia que faz o almoço, tia F., tia J. e a tia M., da lavanderia... a tia F. tá aqui, essa é a casa dela, bonita, né?!" (Lúcia, 6 anos)

- "A tia L. eu amo ela... eu falo que ela é minha mãe... ela levou a gente uma vez pra uma piscina". (Natália, 9 anos)

A experiência da vinculação afetiva permeia o campo das relações de amizade entre as crianças, principalmente para aquelas que se encontram próximas umas das outras. Essa experiência pôde ser observada em dois aspectos: ter e não ter amigos. Essa relação pode ser ilustrada segundo o trecho de um diálogo e de um relato a seguir:

- P: "Do que você mais gosta aqui?"

- J: "Eu gosto daqui; tia, eu vou comprar uma moto amarela... quando eu tiver grande, né, tia?!"

- P: "E como vai ser essa moto?"

- J: "Bem grande, assim, bem bonita... eu gosto muito de moto... e ela vai ser toda amarela! (enquanto falava, J. desenhava e fazia o som da moto)

- P: "E você vai levar alguém com você nessa moto bonita?"

- J:" Vou sim... o João, o Luís, o Carlos... aqui, tia, é eles" (indicava com o dedo os rabiscos coloridos no desenho)
- "P: E eles são seus amigos?"

-J: "Sim, tia... na moto amarela..." (Jorge, 6 anos)

- "Eu não tenho amigos aqui, tia..." (Natália, 9 anos, ao se referir na entrevista às outras crianças com as quais convive no abrigo)

Na descrição da vinculação afetiva, houve a possibilidade de se falar das expectativas que algumas crianças têm com relação a estar em um outro lugar que não seja a instituição.

- "...Eu vou pra casa da minha mãe todo final de semana. Lá é legal, tem Big-Big, pirulito, biscoito, eu gosto de biscoito, e lá tem muito..." (Natália, 9 anos)

- "Olha, tia, eu gostaria, sim... queria ter uma casa..." (Jorge, 6 anos)

Os relatos das crianças versaram acerca da relação bem $x$ mal/certo $x$ errado na experiência da vinculação afetiva, denotando a construção de valores e a forma como estes permeiam as suas relações com outras crianças. Na sala em que foram realizadas as entrevistas, havia um espelho, como é de praxe em salas de atendimento psicológico infantil. O objeto despertou o interesse das crianças, que o utilizaram de forma lúdica. Elas se observavam, viam o seu reflexo no espelho e elaboravam e descreviam um sentido sobre as imagens que estavam observando. Tal sentido era expresso na medida em que o reflexo no espelho representava o lado ruim de sua personalidade, e o lado bom era representado pelo seu próprio corpo real. Elas forneciam um sentido de falso/mal (o reflexo do espelho) e verdadeiro/bem (elas mesmas). Um outro recurso utilizado foi o desenho livre. Sendo de natureza livre o tema do desenho, pôde ser observada a questão da vinculação afetiva, que se apresentou como fenômeno emergente e, quando afirmativo, constatouse que relações e significados relevantes naquele mesmo fenômeno emergente foram percebidos pelas crianças. 
- "Nossa, tia, olha, vai aparecer a outra má... é, essa outra é má, é malvada, e está dentro do espelho..." (Lúcia, 6 anos)

- "Sou eu, tia! É o do mal, tia! Esse é o do bem, essa tia é a do bem... e aquele é do mal, aquela tia é do mal!" (Jorge, 6 anos)

A experiência da vinculação afetiva foi perpassada pelo brincar, no qual a relação e a percepção do outro se fizeram presentes.

- "Tia, se a gente ficar conversando, não vai dar tempo de a gente jogar". (Lúcia, 6 anos)

- "Gosto de brincar de boneca, de água, de brinquedo" (Natália, 9 anos)

- "A Bila, tia, é dessa que eu gosto..." (Carlos, 8 anos)

Nos desenhos, foram identificadas figuras de vinculação das crianças, como cuidadoras do abrigo e amigos mais próximos das crianças. Além destas, elas desenharam a si mesmas, em alguns desenhos, sozinhas, em outros, em conjunto com outras pessoas. Outros desenhos foram representados em paisagens em que havia carros, bicicletas, motos, aviões, que, segundo a elaboração das mesmas, trazia a ideia de pessoas que faziam uso desses veículos, o que dava a noção de movimento aos desenhos. As casas também foram objetos pertinentes expressados através dos desenhos, casas grandes e pequenas com cores vibrantes, fortes, e em primeiro plano no desenho. Figuras representativas como corações e flores apareceram principalmente nos desenhos das meninas e referiam-se a pessoas queridas da instituição, configurando um contexto de afetividade expressado por elas.

Tendo em vista a pesquisa documental realizada nos prontuários das crianças, foram obtidos dados que se referem à sua história de vida. Das quatro crianças, três chegaram ao abrigo por meio do S.O.S Criança, e a outra foi deixada pela mãe. Contudo, obviamente, o percurso de cada uma foi marcado por episódios únicos, bem particulares. No caso das quatro crianças, os pais não haviam assumido a paternidade. As mães de três delas alegaram não possuir condições mínimas de sustentar e criar os filhos. Duas mães apresentaram dependência química de substâncias psicoativas, o que as levava, muitas vezes, a agredir e a negligenciar os filhos. Duas das outras mães apresentavam distúrbios psicológicos graves, sendo que uma tinha crises de epilepsia constantes e os demais familiares não se dispuseram a assumir a guarda da criança, alegando que esta era um problema unicamente da mãe. Essa criança (Carlos), segundo o relatório, apresentava um desenvolvimento cognitivo lento, devido à dispersão e à agitação, e irritava-se facilmente nas atividades escolares. Em grupo, Carlos se mostrava exaltado, muito agressivo, mantendo contato restrito somente com algumas crianças específicas, como Jorge, uma das crianças que também participou desta pesquisa.

A outra mãe, que havia sido diagnosticada com distúrbios mentais, maltratava as duas filhas (Lúcia e a irmã, uma outra criança da instituição com diagnóstico de autismo). Ela dizia ser filha adotiva, e que há mais de dez anos não mantinha contato com os familiares. Além disso, ela não soube informar sobre o pai das crianças. A mãe ainda colocava para a equipe do abrigo que não tinha emprego, ou qualquer outro tipo de renda, nem moradia fixa, e que vivia da boa vontade de pessoas desconhecidas. Lúcia foi diagnosticada com a chamada síndrome de hiperplasia congênita adrenal, que é uma patologia que altera a glândula suprarrenal; logo, ela possuía as genitálias femininas, porém possuía também as genitálias masculinas, mas pouco desenvolvidas. A criança foi submetida a cirurgias e estava sob acompanhamento psicoterapêutico e médico para controle de hormônios. Lúcia apresentava comportamentos que indicavam dificuldade em aceitar limites, necessidade de controle e carência afetiva. 
Uma das crianças, Natália, foi diagnosticada com quadro de anomalia ano-retal e massa gástrica em nível de hipocôndrio direito, além de possuir má-formação nos membros inferiores. Ela foi submetida a várias cirurgias, que, porém, não obtiveram êxito, portanto, é uma criança portadora de deficiência física. Segundo a descrição dos relatórios, Natália é descrita como uma menina esperta, muito comunicativa e de fácil socialização, e que apresenta carência afetiva em inter-relação e manifesta o desejo de ser amada e reconhecida. Das quatro crianças que participaram da pesquisa, todas apresentaram, através de seus prontuários, o histórico de uma infância bastante conturbada, marcada pelo abandono, pela negligência, por agressões físicas e também psicológicas, inseridas em um contexto familiar desfavorável a um desenvolvimento saudável.

\section{Discussão dos resultados}

A perspectiva social que permeia as situações de abrigamento pôde ser identificada nos motivos expostos nos prontuários das crianças que chegaram à instituição, tanto nos casos em que elas foram encaminhadas via S.O.S. Criança como pela própria mãe. O fato que caracteriza o perfil dos pais e da situação econômica da família das crianças expressa de que forma a pobreza, a desigualdade social, a desestrutura familiar, a dependência química e as doenças de ordem mental, física e psicológica afetam as crianças e contribuem para o desfecho de abrigamento. Conforme os dados da pesquisa realizada pela AASPTJ-SP e SAS, algumas causas que levam crianças ao abrigo incluem a violência física e psicológica dentro da família e a falta de condições econômicas mínimas para manter os filhos, dentre outras. De acordo com a pesquisa, $22 \%$ das crianças são levadas devido ao abandono ou negligência, 19\%, devido a problemas relacionados à saúde e a condições sociais desfavoráveis, 10\%, a violência física na família, 10\%, devido ao uso de drogas/alcoolismo pelo pai e/ou mãe, $7 \%$, de entrega da criança a terceiros que não puderam cuidar dela, $7 \%$, devido à morte do pai e/ou mãe, $6 \%$ são crianças em situação de rua, $5 \%$, devido a problemas mentais de pai e/ ou mãe, 4\%, à prisão do pai e/ou mãe, e 10\%, a outras causas não especificadas. Nos casos analisados das quatro crianças referentes a esta pesquisa, todos estariam relacionados a um ou mais fatores descritos acima. Como não foram obtidas informações sobre os pais das crianças, pois, como foi relatado no texto, os pais não sabiam da sua existência, não se pode afirmar qual era a situação em relação aos pais.

A família existe, mas, na maioria dos casos, não possui condições para manter junto de si a criança. Como observa Guará, em relação à pesquisa acima citada, "não existem políticas públicas de apoio a famílias sem condições mínimas de proteger suas crianças". Além da falta de medidas preventivas, também faltam medidas de reabilitação, que permitiriam melhor estruturação familiar para que as crianças pudessem retornar para sua família de origem. As queixas colocadas pelas mães das crianças com relação ao reconhecimento dos filhos pelos pais ilustraram a dificuldade alegada na educação e na permanência das crianças junto a elas. Percebe-se que são estruturas familiares frágeis, complexas, e em que os outros membros da família também não se dispuseram a ajudar a criança, como ocorreu nos casos de Carlos e Jorge. Mascarenhas e Dupas (2001) consideram a família o ponto fundamental de ação para qualquer solução duradoura e persistente do problema da criança e do adolescente, mas que apenas mudará se ocorrerem mudanças na estrutura do modelo de desenvolvimento do País. Da maneira como foi posto, as mães se encontravam sozinhas na criação dos filhos, especialmente nos casos de Lúcia e de Natália, que são portadoras de patologias graves e que exigem cuidados e tratamento constante. 
Outro aspecto importante na questão familiar que é considerado por Santos (2000) é a motivação dos pais/familiares das crianças para estar com elas, ou seja, a autora ressalta a importância de ser considerada a subjetividade dessas pessoas no sentido de se verificar a impossibilidade de as crianças se manterem junto a elas, de os adultos serem responsáveis por elas. Pôde ser observado na história de vida de todas elas o abandono e a negligência da família (parentes) ao se negarem à responsabilidade, quando os pais o fizeram. Nos casos das quatro crianças, o suporte familiar se mostrou falho, bem como o apoio de estruturas sociais e políticas que pudessem oferecer sustentação para que as crianças tivessem a oportunidade de se manter dignamente ao lado das mães e/ou da família.

Quanto às categorias, os resultados obtidos indicaram alguns fatores que estão permeando o vivenciar da vinculação afetiva para as crianças que estão à espera de adoção. Dentre os vários aspectos que emergiram, os que foram anteriormente citados estão presentes no discurso de duas crianças ou mais. Algumas categorias se mostraram bastante interligadas, como o vínculo com a instituição e a possibilidade de se mudarem para outro lugar, fosse ele imaginário ou não. Todas disseram gostar muito da instituição, pois percebem-na como um local bom para se viver. Elas são bem tratadas, o local é agradável, colorido, divertido, e a assistência a elas é prestada de uma forma abrangente, ou seja, com profissionais de várias especialidades a seu serviço, priorizando seu bem-estar. Santos (2000), contudo, enfatiza que a existência de abrigos ideais, ou, pelo menos, com condições melhores, não é suficiente para suportar algo que é mais profundo, porém não menos importante na subjetividade dessas crianças. Ela afirma que, para a criança, não há abrigos de tipo ideal, e, por mais humanizadas e confortáveis que sejam essas instituições, certamente elas não têm recursos e aptidão para preencher as lacunas afetivas/subjetivas e existenciais de quem nelas habita. As crianças que colaboraram com a pesquisa expressaram verbalmente e por desenhos (casas, meios de transporte, etc) seu desejo de ter uma casa, de ir para um local onde possam encontrar um pai ou mãe que as acolha. Apesar de estarem em um lugar de que gostam, em que se sentem acolhidas, há algo que ainda lhes falta, que faz com que elas possam imaginar, ou desejar, poder ir embora, ir para uma casa, onde haverá pessoas de quem gostam, haverá a comida que as satisfaz, ou seja, elas cogitam a possibilidade de ter um lar, um lugar que seja delas, único.

Natália, em seus relatos, ilustra bem essa contradição. Em um primeiro momento, afirma não querer sair da instituição, mas, logo depois, relata que vai para a casa da mãe todos os finais de semana, e lá encontra doces e outras guloseimas, sendo que não há registros formais de que Natália saia do abrigo na constância que relatou. Contudo, é uma criança que elabora suas questões afetivas com fantasia e no brincar, vinculando-se afetivamente a pelo menos uma pessoa do abrigo, a quem ela chama de mãe. Dessa forma, estar abrigada não implica não desejar estar em outro lugar, como uma casa, bem como, para essa criança, estar abrigada também não implica estar abandonada afetivamente, pois ela consegue se vincular a alguém de maneira que essa pessoa possa Ihe servir de referência na instituição. Como Bowlby (1982) considera, a figura de apego se torna necessária para uma vida psíquica saudável, bem como o estabelecimento de outros vínculos com outras pessoas. Assim, a criança procura substitutos para exercer a função materna; logo, a relação que Natália estabelece com a cuidadora a quem chama de mãe não é puramente profissional, pois o vínculo entre ambas parece ir além do que se instituiu como profissional nessa relação, 
torna-se algo da ordem da maternagem. Ressalta-se a importância desse cuidar na relação com as atendentes e com a instituição, pois a representação que as crianças possuem não é apenas da pessoa que está ali por ela, mas da pessoa que tem funções na instituição e que tem um espaço próprio.

Outro fator importante com relação à afetividade é o que emerge do caso de Lúcia, que, apesar de ter uma irmã no abrigo, não citou em nenhum momento o seu nome, dando indícios de que, de fato, em meio ao grupo, alguns laços parecem se enfraquecer. O que emerge da coletividade é que muitas crianças acabam por se tornar irmãs umas das outras, dividindo quartos, roupas, brinquedos e afetos. Winnicott (1975) chama de processo de diferenciação o que se caracteriza até mesmo por um simples brinquedinho ao qual a criança se apega e, que, de qualquer forma, é importante na estruturação da personalidade e da afetividade da criança; nas instituições, muitas vezes, o brinquedo é barrado, no sentido de que a visão do todo, do grupo, deve ser uma só, de que todos são iguais e assim devem permanecer, sem privilégios de qualquer espécie que possam indicar que haja uma diferença no todo.

O brincar parece surgir como elo entre as crianças, com as atendentes e consigo mesmas. Relacionar-se, interagir por meio do brincar é nitidamente colocado por elas quase como condição para que surja algo significativo. No relato das crianças, o brincar emerge como primeiro ponto, como via de acesso ao universo da criança. "É no brincar, e talvez apenas no brincar, que a criança ou o adulto fruem sua liberdade de criação" (Winnicott, 1975, p. 79). O brincar está entre as atividades infantis mais exploradas e significativas para quem trabalha com a criança. Em especial, para Winnicott, o brincar é um momento de criação, do encontro com o simbólico e, principalmente, com o imaginário. O autor lança um olhar para essa atividade no sentido de explorá-la como espaço terapêutico de intervenção e de interação entre a criança e o mundo. Outro ponto que deve ser considerado em relação ao brincar e ao desenvolvimento emocional da criança é que eles implicam necessariamente um encontro com o outro e um encontro consigo mesmo, na elaboração das fantasias, das frustrações e dos desejos da criança.

Quanto às instituições, Altoé (1988) relata que há uma impossibilidade da realização de desejos, fantasias, a expressão de algo que está dentro e que normalmente e salutarmente é colocado para o meio, o que geralmente não ocorre com sujeitos que se encontram sob regras muito mais severas que a regra simbólica existente no mundo, aparentemente livre da sociedade, mas presos em si mesmos. A autora ressalta que o brincar, o lazer, como formas de expressão da subjetividade, são tolhidos pela regras convencionadas dessas instituições, que negam, muitas vezes, às crianças o direito de fazê-lo. Foi possível notar que, no referido abrigo, as crianças tinham muita liberdade para brincar. Elas corriam pelo pátio, podiam pintar, desenhar, escolher brinquedos, brincar com outras crianças, enfim, interagir de forma lúdica e sem maiores preocupações, não havendo um controle rígido por parte dos funcionários. Contudo, observou-se a existência de limites estabelecidos em nível institucional, como horário para brincar, horário para as refeições e horário para ir à escola, de forma que os limites não deixavam de existir mesmo que houvesse a liberdade dentro do abrigo. A instituição citada nesta pesquisa foi descrita como um local de bem-estar pelas crianças, mas que, mesmo sendo representada dessa forma por elas, não impedia que fosse manifestado o desejo de estar em uma casa, ou em uma família. 


\section{Considerações finais}

O problema da infância abandonada e excluída socialmente não encontra suas raízes apenas na atualidade, e sim, na história sociocultural do Brasil, perpassada por falhas sociais e atrelada a um sistema econômico que contribui para a exclusão, a marginalização e a limitação de possibilidades. Além desses fatores, ainda emergem as questões intersubjetivas, no sentido de que também estão sujeitas à cultura. Logo, existem conflitos internos que influenciam no abandono das crianças, mas que estão em diálogo intenso e inter-relacional com as produções sociais de representação, de estigmatização e de preconceito. Uma estrutura familiar disfuncional que é precária de subjetividade, de afeto, bem como de condições econômicas, reflete a fragilidade das relações sociais e interpessoais, e coloca o sujeito em um lugar de conflito e de abandono, como é o caso das crianças e de suas famílias, que não reúnem condições nem psicológicas, nem físicas, nem econômicas para oferecer o mínimo de sustentação aos seus membros.

A instituição, por sua vez, entra como ponto de apoio, como sustentação para as dificuldades, consideradas intransponíveis para essas crianças e suas mães em um dado momento de suas vidas. O abrigamento, como medida de proteção, também acaba por se tornar um paradoxo. Com o objetivo de proteger a criança, é violado seu direito à liberdade, o de ser tratada como um ser único, individualizado, o que dificulta seu processo de construção de identidade. A possibilidade de desenvolver vínculos afetivos significativos se torna remota e com rupturas frequentes, o que atinge a criança em sua segurança pessoal, em sua confiança em si e no outro, configurando relações mal-elaboradas psiquicamente. Os comportamentos de agressão, retraimento, irritabilidade e distanciamento, bem como os comportamentos de aproximação rápida e intensa, podem indicar a carência e a pobreza afetiva em que se encontram crianças em situação de abrigamento ou de abandono. De certa forma, são movimentos distintos, mas que representam dificuldade de se relacionar, de estabelecer vínculos afetivos saudáveis e significativos bem como de expressar a afetividade para consigo mesmas e para com o outro com quem se vincula.

Parece nítido que a questão do abandono e a situação de abrigamento interferem na vinculação afetiva de modo significativo. Contudo, a adoção não representa a solução final para a infância abrigada, ou mesmo abandonada, mas apenas uma das alternativas de proteção propostas pelo Estatuto da Criança e do Adolescente. De fato, reconhece-se que pode ser a melhor de que a sociedade dispõe atualmente, mesmo com suas falhas e percalços. No movimento de minimizar a institucionalização, ela constitui uma das soluções mais visíveis na atualidade e sobre a qual se tem debruçado profissionais e estudiosos. A iniciativa de grupos de adoção é um caminho alternativo para essa discussão no sentido de problematizar os conflitos advindos de uma prática tão antiga, que, mesmo assim, tem se submetido às transformações sociais e culturais.

Tratar de adoção significa tratar de vínculos estabelecidos consanguínea, juridica e afetivamente. Adotar presume estar com um outro e relacionar-se afetivamente com esse outro, logo o cuidado de que se devem imbuir os profissionais que atuam na área para realizar essas rupturas, para facilitar o estabelecimento de novos vínculos entre a criança, os novos pais e a instituição. Repensar os contextos social, econômico e político em que essas crianças estão inseridas auxilia na compreensão de que se trata de um conjunto bem maior (macro), que engloba os conjuntos privados, subjetivos (micro) da sociedade e amplia o entendimento de que soluções efetivas, eficazes e duradouras demandam tempo, investimento e transformações culturais, portanto, intersubjetivas, logo, produzidas entre sujeitos e para sujeitos. 
Shimênia Vieira de Oliveira*

Psicóloga clínica. Mestranda em Psicologia da Intersubjetividade pela Universidade Federal de Uberlândia, Uberlândia, MG - Brasil.

\section{Caio César Souza Camargo Próchno}

Pós-Doutor em Filosofia e Psicologia pela Universidade de Leipzig, Leipzig - Alemanha. Professor associado II do Instituto de Psicologia da Universidade Federal de Uberlândia, Uberlândia, MG - Brasil.

E-mail: c.prochno@uol.com.br

\section{*Endereço para envio de correspondência:}

Av. dos Jardins, no 250, casa 195, Condomínio Jardim Barcelona, Nova Uberlândia - Uberlândia, MG - Brasil - CEP: 38412-639.

E-mail: shimenia.isi@netsite.com.br

Recebido 28/10/2008, 1aㅡ Reformulação 5/6/2009, 2ª Reformulação 7/8/2009, Aprovado 20/8/2009. 
Albuquerque, M. T. (1983). Adoção e menor abandonado: conhecimentos, opiniões e atitudes. Dissertação de Mestrado, Escola Paulista de Medicina, São Paulo.

Altoé. S. (1988). Infâncias perdidas. Rio de Janeiro: Xenon.

Alves-Mazzoti, A. J. E. (1999). O método qualitativo nas ciências naturais e sociais: pesquisa quantitativa e qualitativa (2a ed.). São Paulo: Pioneira.

Ballone, G. B. (2003). A criança adotada e de orfanato. Psiqweb, psiquiatria geral. Disponível em: <http://www.psiqweb.med br/infantil/adpc.html >. Revisto em 2003.

Bowlby, J. (1982). Formação e rompimento dos laços afetivos. São Paulo: Martins.

Bowlby, J. (1980). Apego e perda: tristeza e depressão. São Paulo: Martins Fontes.

Bussab, V. S. R (2003). Compartilhamentos, afetos e implicações para a co-educação de gerações: reflexões a partir de uma perspectiva evolucionária. In Congresso Internacional $\mathrm{Co}-$ Educação de Gerações. São Paulo: SESC.

Cartilha de Adoção. (2004). 2ª Vara da Infância e da Juventude do Recife e Comissão Estadual Judiciária de Adoção - CEJA/PE.

Código Civil. (2003). Código de Processo Civil. Obra coletiva de autoria da Revista dos Tribunais (5a ed.) (Y. S. Cahali, Org.; G. de M. Braga Tapai \& A. P. Alexandre et al., Coords.). São Paulo: Revista dos Tribunais.

Estatuto da Criança e do Adolescente. (1990, julho). Lei $n^{\circ}$ 8.069. Brasília, DF.

Família Acolhedora - um projeto Selo Amigo da CEJAl - CE. (2005). Disponível em: http://www.sas.ce.gov.br

Forghieri, Y. C. (1993). Psicologia fenomenológica: fundamentos, método e pesquisa (Biblioteca Pioneira de Ciências Sociais e Psicologia). São Paulo: Pioneira.

Fu, L., \& Matarazzo, E. B. (2001, setembro). Prevalência de adoção intra e extrafamiliar em amostras clínica e não-clínica de crianças e adolescentes. Revista Brasileira de Psiquiatria, 23(3), 149-155.

Gomes, W. (Org.). (1998). Fenomenologia e pesquisa em psicologia. Porto Alegre: Universidade Federal do Rio Grande do Sul.

Lôbo, P. L. N. (2006). Do poder familiar. Disponível em: <http: jus2.uol.com.br/doutrina/texto.asp?id $=8371>.2006$

Marcílio, M. L. (1998). História social da criança abandonada. São Paulo: Hucitec.

Mariano, F. N., \& Rossetti-Ferreira, M. C. (2008). Que perfil da família biológica e adotante, e da criança adotada revelam os processos judiciais? Psicologia: Reflexão e Crítica, 21(1), $11-19$
Mascarenhas, S. H. Z., \& Dupas, G. (dez. 2001). Conhecendo a experiência de crianças institucionalizadas. Revista da Escola de Enfermagem da USP, 35(4), 413-419.

Moreira, V. (2004). O método fenomenológico de Merleau-Ponty como ferramenta crítica na pesquisa em psicopatologia. Psicologia: Reflexão e Crítica, 17(3), 447-456.

Peres, A. P. A. B. (2006). A adoção por homossexuais: fronteiras da família na pós-modernidade. Rio de Janeiro: Renovar.

Ribeiro, M. O., \& Ciampone, M. H. T. (dez. 2002). Crianças em situação de rua falam sobre os abrigos. Revista da Escola de Enfermagem da USP, 36(4), 309-316.

Santos, L. (2000). Adoção ou abrigos de tipo ideal? Serviço Social e Sociedade, 21(63), 76-93.

Santos, T. S. (2001). Globalização e exclusão: a dialética da mundialização do capital. Sociologias, 3(6), 170-198.

Sartorelli, J. B., Claro, M. M. F., \& Botomé, S. P. (2003). Adoção, uma aprendizagem de amor possível. Interação em Psicologia, $7(2), 129-130$

Soares, J. (2005). Abrigos em questão. Camargo Correa, 6(28). Grupo Camargo Correa.

Tabajaski, B., \& Chaves, V. P. (1997). Uma experiência profilática a preparação de crianças para adoção. Trabalho apresentado no I Congresso Internacional de Saúde Mental, Canela, RS.

Valiko, F.A.B. (2003). Adoção à luz do Estatuto da Criança e do Adolescente e do novo Código Civil.

Weber, L. N. D. (1998). Laços de ternuras: pesquisas e histórias de adoção. Curitiba: Santa Mônica.

Weber, L. N. D. (2003). Aspectos psicológicos da adoção (2a ed.). Curitiba: Juruá Editora.

Weber, L. N. D. (2002). Pais e filhos por adoção no Brasil: características, expectativas e sofrimentos. Curitiba: Juruá Editora.

Winnicott, D. W. (1975). O brincar e a realidade. Rio de Janeiro: Imago.

Winnicott, D. W. (1985). A criança e o seu mundo (6a ed.). Rio de Janeiro: Zahar Editores. 